\title{
Transactions
}

Cite this: Dalton Trans., 2012, 41, 173

wWW.rsc.org/dalton

PAPER

\section{Dinuclear Rh(II) pyrazolates as CVD precursors for rhodium thin films $\dagger$}

\author{
W. Jeffrey McCarty, Xiaoping Yang, Lauren J. DePue Anderson and Richard A. Jones* \\ Received 31st August 2011, Accepted 8th October 2011 \\ DOI: $10.1039 /$ c1dt11649e
}

New dinuclear rhodium(II) pyrazolate $(\mathrm{Pz})$ complexes of formula $\mathrm{Rh}_{2}\left(3-\mathrm{R}, 5-\mathrm{R}^{\prime} \mathrm{Pz}\right)_{4} \cdot 2 \mathrm{~L}\left(\mathrm{R}=\mathrm{R}^{\prime}=\mathrm{CF}_{3}\right.$, $\left.\mathrm{L}=\mathrm{H}_{2} \mathrm{O}(\mathbf{1}), \mathrm{CH}_{3} \mathrm{CN}(\mathbf{2})\right)$ and $\mathrm{Rh}_{2}\left(3-\mathrm{R}, 5-\mathrm{R}^{\prime} \mathrm{Pz}\right)_{4}\left(\mathrm{R}=\mathrm{R}^{\prime}={ }^{t} \mathrm{Bu}(\mathbf{3}) ; \mathrm{R}=\mathrm{CF}_{3}, \mathrm{R}^{\prime}={ }^{t} \mathrm{Bu}(\mathbf{4})\right)$ have been synthesized from the interaction of the lithium salt of the corresponding pyrazole with $\mathrm{Rh}_{2}(\mathrm{OAc})_{4}$ in diethyl ether. The complexes were characterized by X-ray crystallography and spectroscopic methods. They were further evaluated as precursors for the chemical vapor deposition (CVD) of $\mathrm{Rh}$ thin films using $\mathrm{H}_{2}$ as the carrier gas. The resulting films were characterized by scanning electron microscopy (SEM), X-ray diffraction (XRD) and X-ray photoelectron spectroscopy (XPS).

\section{Introduction}

Thin films of rhodium are used as reflective ${ }^{1}$ and catalytic ${ }^{2}$ coatings, as diffusion barriers and interconnect layers in microelectronic devices, ${ }^{3}$ and in chemical sensing applications. ${ }^{4}$ Typically the volatile organometallic precursors studied for the chemical vapor deposition (CVD) of rhodium films contain acetylacetonato, ${ }^{5} \eta^{5}$ cyclopentadienenyl and allyl ligands, ${ }^{6}$ which incorporate direct $\mathrm{Rh}-\mathrm{O}$ or $\mathrm{Rh}-\mathrm{C}$ bonds, and thus could pose a possible source for film contamination by $\mathrm{O}$ or $\mathrm{C}$. Also, the synthesis of precursors which feature multiple varieties of ligands to fill the coordination sphere of the metal tend to involve low-yield, multistep syntheses. Both of these issues are of concern for CVD coating applications where the goal is the production of low-cost, high-purity films. Of interest to the work described in this paper are the findings of Kumar and Puddephatt who showed that the use of hydrogen as the carrier gas for $\mathrm{Rh}$ thin film CVD produced films of higher purity. ${ }^{6 a}$

$\mathrm{We}^{7}$ and others ${ }^{8}$ have investigated the use of the 3,5-disubstituted pyrazolate moiety $(\mathrm{Pz})$ as a promising ligand for volatile precursors for CVD of transition metal thin films. The pyrazolate ligand is able to support a wide variety of coordination modes and its relatively high thermal stability minimizes decomposition, which should lead to low levels of impurities in the grown film. We report here the synthesis and structural characterization of four new $\mathrm{Rh}$ (II) $\mu$-pyrazolate complexes of formula $\mathrm{Rh}_{2}(3-\mathrm{R}, 5-$ $\left.\mathrm{R}^{\prime} \mathrm{Pz}\right)_{4} \cdot 2 \mathrm{~L}\left(\mathrm{R}=\mathrm{R}^{\prime}=\mathrm{CF}_{3}, \mathrm{~L}=\mathrm{H}_{2} \mathrm{O}(\mathbf{1}), \mathrm{CH}_{3} \mathrm{CN}(\mathbf{2})\right)$ and $\mathrm{Rh}_{2}(3-\mathrm{R}, 5-$ $\left.\mathrm{R}^{\prime} \mathrm{Pz}\right)_{4}\left(\mathrm{R}=\mathrm{R}^{\prime}={ }^{t} \mathrm{Bu}(3) ; \mathrm{R}=\mathrm{CF}_{3}, \mathrm{R}^{\prime}={ }^{t} \mathrm{Bu}(\mathbf{4})\right)$. These rhodium pyrazolate complexes present interesting possibilities for CVD applications due to their air and thermal stability, high-yielding synthesis, and high metal to ligand ratio. We have found that the

Department of Chemistry and Biochemistry, The University of Texas at Austin, 1 University Station, A5300, Austin, Texas, 78712-0165, USA. E-mail: rajones@mail.utexas.edu; Tel: +1 (512)471-1706

$\dagger$ CCDC reference numbers 772325 and 840523-840525. For crystallographic data in CIF or other electronic format see DOI: $10.1039 / \mathrm{c} 1 \mathrm{dt} 11649 \mathrm{e}$ volatilities of the compounds vary depending on the substitution of the bridging pyrazolate ligand, and preliminary results of the CVD of rhodium films from these complexes are reported in this paper.

\section{Results and discussion}

Reaction of anhydrous $\mathrm{Rh}_{2}(\mathrm{OAc})_{4}$ with four equivalents of the corresponding lithiated pyrazolate in diethyl ether at $25{ }^{\circ} \mathrm{C}$ produces 1-4 in good yields (Scheme 1). The compounds can be isolated as X-ray quality crystals by crystallization from hexane at $-30{ }^{\circ} \mathrm{C}$ or by sublimation of the crude reaction product under reduced pressure at temperatures ranging from $140-210^{\circ} \mathrm{C}$. The Xray crystal structures show that the complexes all possess a central core consisting of two Rh(II) centers bridged by four pyrazolate units in the classic paddlewheel configuration most commonly found in dinuclear Rh(II) carboxylate complexes. The only other known dinuclear Rh-bridged pyrazolate system of this type is the 3,5-(Me $)_{2}$ Pz analog reported by Wilkinson and co-workers, ${ }^{9}$ while a tin pyrazolate complex of this type is also known. ${ }^{10}$

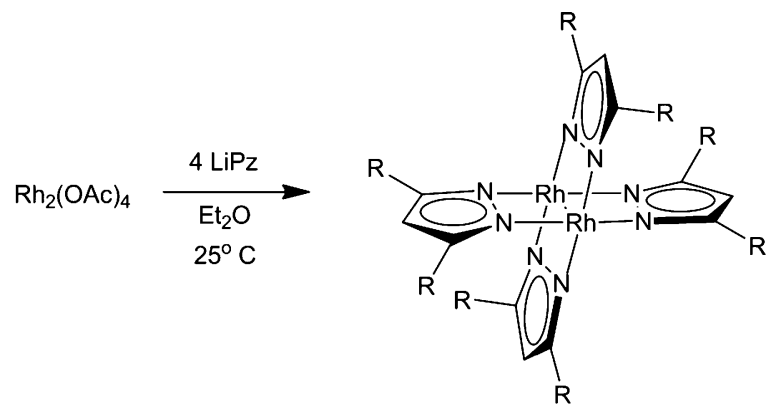

Scheme 1 Synthesis of dinuclear Rh(II) pyrazolate complexes.

Complex 1 crystallizes in the $P 2_{1} / n$ space group with two molecules per unit cell (Fig. 1). An inversion center resides midway between the $\mathrm{Rh}$ atoms, leading to crystallographically imposed planarity of the ligands with respect to the $\mathrm{Rh}-\mathrm{Rh}$ bond. The 
Table 1 Crystal data and structure refinement for complexes 1-4

\begin{tabular}{|c|c|c|c|c|}
\hline & 1 & 2 & 3 & 4 \\
\hline Empirical formula & $\mathrm{C}_{20} \mathrm{H}_{8} \mathrm{~F}_{24} \mathrm{~N}_{8} \mathrm{O}_{2} \mathrm{Rh}_{2}$ & $\mathrm{C}_{12} \mathrm{H}_{5} \mathrm{~F}_{12} \mathrm{~N}_{5} \mathrm{Rh}$ & $\mathrm{C}_{44} \mathrm{H}_{76} \mathrm{~N}_{8} \mathrm{Rh}_{2}$ & $\mathrm{C}_{16} \mathrm{H}_{20} \mathrm{~F}_{6} \mathrm{~N}_{4} \mathrm{Rh}$ \\
\hline Formula weight & 1054.16 & 550.12 & 922.95 & 485.27 \\
\hline Temperature (K) & $100(2)$ & $100(2)$ & $153(2)$ & $153(2)$ \\
\hline Crystal system & monoclinic & triclinic & monoclinic & tetragonal \\
\hline Space group & $P 2_{1} / n$ & $P \overline{1}$ & $C 2 / c$ & $I 4_{1} / a$ \\
\hline$a(\AA)$ & $9.2451(11)$ & $9.359(1)$ & $15.823(3)$ & $19.360(10)$ \\
\hline$b(\AA)$ & $18.048(2)$ & $9.434(1)$ & $15.106(3)$ & $19.360(10)$ \\
\hline$c(\AA)$ & $9.3478(11)$ & $10.913(1)$ & $21.085(4)$ & $10.173(5)$ \\
\hline$\alpha\left({ }^{\circ}\right)$ & 90 & $109.56(3)$ & 90 & 90 \\
\hline$\beta\left(^{\circ}\right)$ & $103.683(3)$ & $102.23(3)$ & $110.28(3)$ & 90 \\
\hline$\gamma\left({ }^{\circ}\right)$ & 90 & $92.58(3)$ & 90 & 90 \\
\hline Volume $\left(\AA^{3}\right)$ & $1515.5(3)$ & $880.20(19)$ & $4727.2(2)$ & $3812.9(3)$ \\
\hline$Z$ & 2 & 2 & 4 & 8 \\
\hline$\rho_{\text {calc }}\left(\mathrm{g} \mathrm{cm}^{-1}\right)$ & 2.31 & 2.076 & 1.297 & 1.691 \\
\hline$F(000)$ & 1012 & 530 & 1944 & 1944 \\
\hline Theta range $\left({ }^{\circ}\right)$ & $3.01-27.48$ & $3.01-27.46$ & $3.15-25.00$ & $2.26-27.53$ \\
\hline Reflections collected & 27098 & 25948 & 7478 & 9983 \\
\hline Independent reflections & $3456,\left(R_{\mathrm{int}}=0.0441\right)$ & $4017,\left(R_{\text {int }}=0.0281\right)$ & $4143,\left(R_{\mathrm{int}}=0.0245\right)$ & $2189,\left(R_{\mathrm{int}}=0.0862\right)$ \\
\hline GOF & 1.098 & 0.988 & 1.078 & 1.107 \\
\hline$R_{1}, \mathrm{w} R_{2}[I>2 \sigma(I)]^{a}$ & $0.0260,0.0559$ & $0.0207,0.0494$ & $0.0247,0.0536$ & $0.0590,0.1153$ \\
\hline$R_{1}$, w $R_{2}$ (all data $)^{a}$ & $0.0292,0.0573$ & $0.0222,0.0500$ & $0.0437,0.0599$ & $0.1327,0.1435$ \\
\hline Largest diff. peak, hole (e $\left.\AA^{3}\right)$ & $0.449,-0.542$ & $0.563,-0.468$ & $0.325,-0.472$ & $2.067,-0.778$ \\
\hline
\end{tabular}

Table 2 Selected bond lengths $(\AA)$ and angles $\left({ }^{\circ}\right)$ for $\mathbf{1}$ and $\mathbf{2}^{a}$

\begin{tabular}{llll}
\hline & \multicolumn{3}{c}{$\mathbf{2}$} \\
\hline $\mathrm{Rh}(1)-\mathrm{N}(1)$ & $2.062(6)$ & $\mathrm{Rh}(1)-\mathrm{N}(1)$ & $2.064(17)$ \\
$\mathrm{Rh}(1)-\mathrm{N}(2)$ & $2.060(6)$ & $\mathrm{Rh}(1)-\mathrm{N}(2)$ & $2.061(16)$ \\
$\mathrm{Rh}(1)-\mathrm{N}(3)$ & $2.056(6)$ & $\mathrm{Rh}(1)-\mathrm{N}(3)$ & $2.054(16)$ \\
$\mathrm{Rh}(1)-\mathrm{N}(4)$ & $2.058(6)$ & $\mathrm{Rh}(1)-\mathrm{N}(4)$ & $2.060(17)$ \\
$\mathrm{Rh}(1)-\mathrm{O}(1)$ & $2.282(5)$ & $\mathrm{Rh}(1)-\mathrm{N}(5)$ & $2.149(17)$ \\
$\mathrm{Rh}(1)-\mathrm{Rh}(1)^{\prime}$ & $2.343(11)$ & $\mathrm{Rh}(1)-\mathrm{Rh}(1)^{\mathrm{i}}$ & $2.353(3)$ \\
$\mathrm{N}(1)-\mathrm{N}(3)^{\prime}$ & $1.365(8)$ & $\mathrm{N}(5)-\mathrm{C}(11)$ & $1.138(3)$ \\
$\mathrm{N}(4)-\mathrm{N}(2)^{\prime}$ & $1.358(8)$ & $\mathrm{C}(11)-\mathrm{C}(12)$ & $1.463(4)$ \\
& & $\mathrm{N}(1)-\mathrm{N}(3)^{\mathrm{i}}$ & $1.358(2)$ \\
$\mathrm{N}(1)-\mathrm{Rh}(1)-\mathrm{N}(2)$ & $86.76(2)$ & $\mathrm{N}(1)-\mathrm{Rh}(1)-\mathrm{N}(2)$ & $86.80(7)$ \\
$\mathrm{N}(1)-\mathrm{Rh}(1)-\mathrm{N}(3)$ & $152.52(2)$ & $\mathrm{N}(1)-\mathrm{Rh}(1)-\mathrm{N}(3)$ & $152.03(7)$ \\
$\mathrm{N}(1)-\mathrm{Rh}(1)-\mathrm{O}(1)$ & $105.12(2)$ & $\mathrm{N}(1)-\mathrm{Rh}(1)-\mathrm{N}(5)$ & $103.39(7)$ \\
$\mathrm{N}(1)-\mathrm{Rh}(1)-\mathrm{Rh}(1)^{\prime}$ & $76.42(16)$ & $\mathrm{N}(2)-\mathrm{Rh}(1)-\mathrm{N}(5)$ & $101.90(7)$ \\
$\mathrm{O}(1)-\mathrm{Rh}(1)-\mathrm{Rh}(1)^{\prime}$ & $177.68(13)$ & $\mathrm{N}(1)-\mathrm{Rh}(1)-\mathrm{Rh}(1)^{\mathrm{i}}$ & $75.74(5)$ \\
& & $\mathrm{N}(5)-\mathrm{Rh}(1)-\mathrm{Rh}(1)^{\mathrm{i}}$ & $177.60(5)$ \\
& & $\mathrm{C}(11)-\mathrm{N}(5)-\mathrm{Rh}(1)$ & $167.20(17)$ \\
& & $\mathrm{N}(5)-\mathrm{C}(11)-\mathrm{C}(12)$ & $177.20(2)$
\end{tabular}

${ }^{a}$ Symmetry transformations used to generate equivalent atoms: ${ }^{\prime}-x,-y,-z$; i $-x+1,-y,-z+1$.

short $\mathrm{Rh}-\mathrm{Rh}$ interaction of $2.343 \AA$ is indicative of a single bond, while the $\mathrm{Rh}-\mathrm{N}$ bond distances range from 2.056 to 2.062 $\AA$ and are typical of both mononuclear and bridged rhodium pyrazolate complexes. Selected bond lengths and angles are listed in Table 2. The 5 hydrogen atoms of the axially coordinated water molecules were found in the electron difference map and were refined isotropically with fixed O-H distances of $0.807 \AA$ and 0.805 $\AA$ for $\mathrm{H}(1)$ and $\mathrm{H}(2)$, respectively. The oxygen atoms of the water molecules on adjacent $\mathrm{Rh}_{2}(\mathrm{Pz})_{4}$ units in the lattice are sufficiently close to each other to suggest intermolecular hydrogen bonding through $\mathrm{O}-\mathrm{H} \cdots \mathrm{O}$ linkages $\left(\mathrm{O}(1)-\mathrm{O}(1)^{\mathrm{i}}=2.915 \AA\right)$. However the $\mathrm{O}-\mathrm{H} \cdots \mathrm{F}$ distances of $2.487 \AA$ and $2.611 \AA$ for $\mathrm{H}(1) \cdots \mathrm{F}(3)^{\mathrm{i}}$ and $\mathrm{H}(2) \cdots \mathrm{F}(2)^{\mathrm{i}}$, respectively, as well as the large average $\mathrm{O}-\mathrm{H} \cdots \mathrm{F}$ angle of $122^{\circ}$ indicate significant electrostatic interaction of the
Table 3 Hydrogen bond lengths $(\AA)$ and angles $\left({ }^{\circ}\right)$ for complex $\mathbf{1}^{a}$

\begin{tabular}{lcccc}
\hline $\mathrm{D}-\mathrm{H} \cdots \mathrm{A}$ & $d(\mathrm{D}-\mathrm{H})$ & $d(\mathrm{H} \cdots \mathrm{A})$ & $d(\mathrm{D} \cdots \mathrm{A})$ & $<(\mathrm{DHA})$ \\
\hline $\mathrm{O}(1)-\mathrm{H}(1) \cdots \mathrm{F}(3)^{\mathrm{i}}$ & $0.8050(18)$ & $2.4866(15)$ & $3.082(2)$ & $131.76(14)$ \\
$\mathrm{O}(1)-\mathrm{H}(2) \cdots \mathrm{F}(2)^{\mathrm{i}}$ & $0.8050(18)$ & $2.6108(15)$ & $3.039(2)$ & $114.94(14)$ \\
$\mathrm{O}(1)-\mathrm{H}(1) \cdots \mathrm{O}(1)^{\mathrm{i}}$ & $0.8072(19)$ & $2.7511(18)$ & $2.915(4)$ & $93.59(13)$ \\
${ }^{a}$ Symmetry transformations & used to generate equivalent atoms: \\
${ }^{\mathrm{i}}-x,-y,-z$. &
\end{tabular}

water molecules with fluorine atoms on neighboring pyrazolate ligands (Table 3). As shown in Fig. 2, this hydrogen bonding interaction results in packing of the crystals into one-dimensional coordination networks of $\mathrm{Rh}_{2}(\mathrm{Pz})_{4}\left(\mathrm{H}_{2} \mathrm{O}\right)_{2}$ molecules.

The solid state structure of $\mathbf{2}$ is shown in Fig. 1 and key bond lengths and angles are listed in Table 2 . The molecule has nearly identical metrical parameters to the water adduct (1), although the $\mathrm{Rh}-\mathrm{Rh}$ bond length for $\mathbf{2}$ is slightly longer than that in $\mathbf{1}(\mathrm{Rh}-$ $\mathrm{Rh}: 2.353 \AA$ ). One possible explanation for this lengthening is the difference in $\sigma$ donating ability of acetonitrile vs. water. Better overlap of the ligand orbitals with the $\sigma^{*}$ LUMO of the complex, which is antibonding with respect to the $\mathrm{Rh}-\mathrm{Rh}$ interaction and occupies the area along the rotational axis of the complex, would result in a relative weakening of the Rh-Rh interaction in $\mathbf{2} v s . \mathbf{1}$. Although we were unable to isolate the binary dinuclear complex $\mathrm{Rh}_{2}\left(\left(\mathrm{CF}_{3}\right)_{2} \mathrm{Pz}\right)_{4}$ without axial donor ligands, loss of both $\mathrm{H}_{2} \mathrm{O}$ and $\mathrm{MeCN}$ from $\mathbf{1}$ and $\mathbf{2}$ was observed by $\mathrm{CI}$ mass spectrometry. Peaks at $m / e 1018\left(\mathrm{M}^{+}-2 \mathrm{H}_{2} \mathrm{O}\right)$ and $998\left(\mathrm{M}^{+}-2 \mathrm{H}_{2} \mathrm{O}-\mathrm{F}\right)$ dominate the spectrum of $\mathbf{1}$, with a very low intensity signal at $m / e 1034$, representing coordination of one water molecule to the parent ion. Similarly, the CI mass spectrum of the acetonitrile adduct $\mathbf{2}$ shows peaks corresponding to loss of one $(\mathrm{m} / \mathrm{e}$ 1059) and both $(\mathrm{m} / \mathrm{e}$ 1018) coordinated solvent molecules.

Complex 3 crystallizes in the monoclinic space group $C 2 / c$ with four molecules per unit cell (Fig. 3). Each 3,5-( $\left.{ }^{t} \mathrm{Bu}\right)_{2} \mathrm{Pz}$ ligand 
(a)

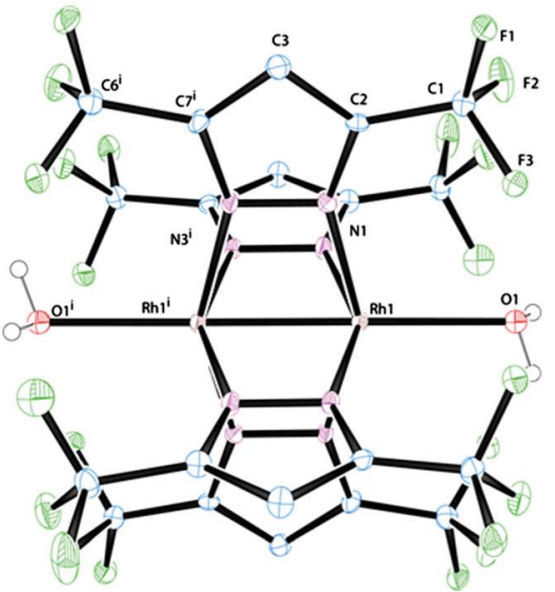

(b)

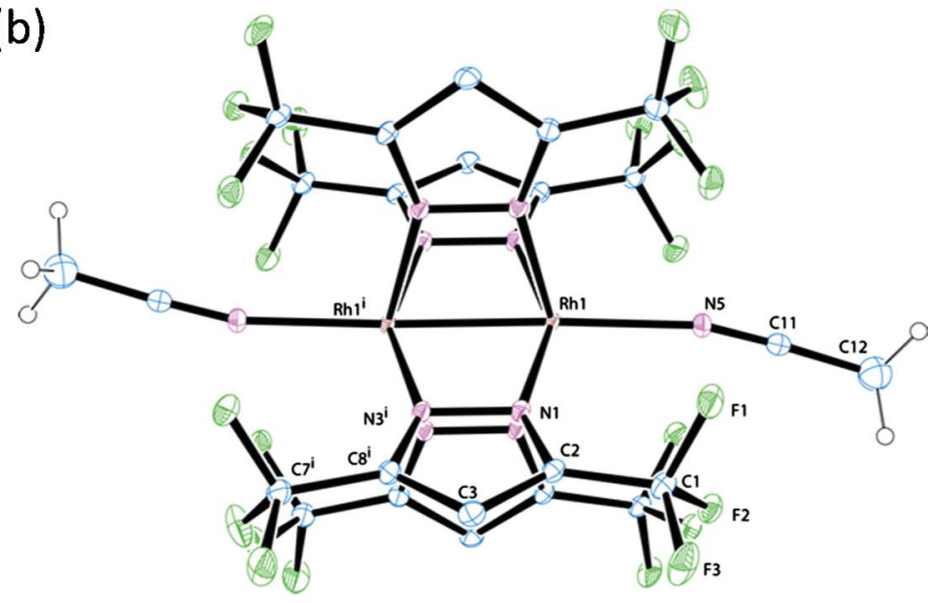

Fig. 1 ORTEP representation of (a) $\mathrm{Rh}_{2}\left(\mu-3,5-\left(\mathrm{CF}_{3}\right)_{2} \mathrm{Pz}\right)_{4} \cdot 2 \mathrm{H}_{2} \mathrm{O}$ (1) and (b) $\mathrm{Rh}_{2}\left(\mu-3,5-\left(\mathrm{CF}_{3}\right)_{2} \mathrm{Pz}\right)_{4} \cdot 2 \mathrm{CH}_{3} \mathrm{CN}(\mathbf{2})$ with thermal ellipsoids drawn at the $30 \%$ probability level. Hydrogen atoms on the pyrazolate ligands have been omitted for clarity.

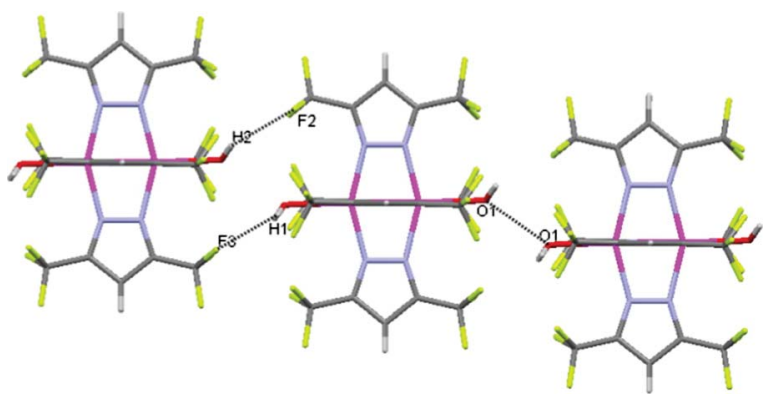

Fig. 2 Intramolecular hydrogen bonding interactions of $\mathbf{1}$.

Table 4 Selected bond lengths ( $\AA$ ) and angles $\left({ }^{\circ}\right)$ for $\mathbf{3}$ and $\mathbf{4}^{a}$

\begin{tabular}{|c|c|c|c|}
\hline \multicolumn{2}{|l|}{3} & \multicolumn{2}{|l|}{4} \\
\hline $\mathrm{Rh}(1)-\mathrm{N}(1)$ & $2.064(2)$ & $\mathrm{Rh}(1)-\mathrm{N}(1)$ & $2.069(6)$ \\
\hline $\mathrm{Rh}(1)-\mathrm{N}(2)$ & $2.058(2)$ & $\mathrm{Rh}(1)-\mathrm{N}(2)$ & $2.033(6)$ \\
\hline $\mathrm{Rh}(1)-\mathrm{N}(3)$ & $2.059(2)$ & $\mathrm{Rh}(1)-\mathrm{N}(1)^{\mathrm{i}}$ & $2.069(6)$ \\
\hline $\mathrm{Rh}(1)-\mathrm{N}(4)$ & $2.061(2)$ & $\mathrm{Rh}(1)-\mathrm{N}(2)^{\mathrm{i}}$ & $2.033(6)$ \\
\hline $\operatorname{Rh}(1)-\operatorname{Rh}(1)^{\prime}$ & $2.305(8)$ & $\operatorname{Rh}(1)-\operatorname{Rh}(1)^{\mathrm{iii}}$ & $2.3081(15$ \\
\hline $\mathrm{N}(1)-\mathrm{Rh}(1)-\mathrm{N}(2)$ & $87.25(9)$ & $\mathrm{N}(1)-\mathrm{Rh}(1)-\mathrm{N}(2)$ & $86.68(5)$ \\
\hline $\mathrm{N}(1)-\mathrm{Rh}(1)-\mathrm{N}(3)$ & $153.45(7)$ & $\mathrm{N}(1)-\mathrm{Rh}(1)-\mathrm{N}(1)^{\mathrm{i}}$ & $152.04(6)$ \\
\hline $\mathrm{N}(1)-\mathrm{Rh}(1)-\mathrm{N}(4)$ & $87.15(9)$ & $\mathrm{N}(1)-\mathrm{Rh}(1)-\mathrm{Rh}(1)^{\mathrm{ii}}$ & $76.02(2)$ \\
\hline $\mathrm{N}(1)-\mathrm{Rh}(1)-\mathrm{Rh}(1)^{\prime}$ & $76.81(6)$ & $\mathrm{N}(2)^{\mathrm{i}}-\mathrm{Rh}(1)-\mathrm{Rh}(1)^{\mathrm{ii}}$ & $77.18(2)$ \\
\hline $\mathrm{N}(2)-\mathrm{Rh}(1)-\mathrm{Rh}(1)^{\prime}$ & $76.75(6)$ & $\mathrm{N}(1)^{\mathrm{iii}}-\mathrm{N}(2)-\mathrm{Rh}(1)$ & $103.91(4)$ \\
\hline $\mathrm{N}(1)^{\prime}-\mathrm{N}(1)-\mathrm{Rh}(1)$ & $102.46(6)$ & $\mathrm{N}(2)^{\mathrm{ii}}-\mathrm{N}(1)-\mathrm{Rh}(1)$ & $102.88(4)$ \\
\hline $\mathrm{N}(2)^{\prime}-\mathrm{N}(4)-\mathrm{Rh}(1)$ & $102.23(13)$ & & \\
\hline $\mathrm{Rh}(1)-\mathrm{N}(1)-\mathrm{N}(1)^{\prime}-\mathrm{Rh}(1)^{\prime}$ & 10.92 & & \\
\hline $\mathrm{Rh}(1)-\mathrm{N}(2)-\mathrm{N}(4)^{\prime}-\mathrm{Rh}(1)^{\prime}$ & 10.68 & & \\
\hline
\end{tabular}

${ }^{a}$ Symmetry transformations used to generate equivalent atoms: ${ }^{\prime}-x, y,-z+$ $1 / 2 ;{ }^{i}-x+2,-y+1 / 2, z$; ii $y+3 / 4,-x+5 / 4,-z+5 / 4$; iii $-y+5 / 4, x-$ $3 / 4,-z+5 / 4$

is tilted slightly such that the pyrazolate rings are not perfectly co-linear with the $\mathrm{Rh}-\mathrm{Rh}$ bond (angle between two opposite pyrazolate rings $19.8^{\circ}$ av.). This deviation from $D_{4 h}$ symmetry is seen in other dinuclear systems with sterically demanding ligands, ${ }^{11}$ and likely allows for better packing of the large ${ }^{t} \mathrm{Bu}$ groups around the $\mathrm{Rh}_{2}$ core. The $\mathrm{Rh}-\mathrm{N}$ distances are similar to those found in complex $\mathbf{1}$. Other key bond lengths and angles are listed in Table 4.

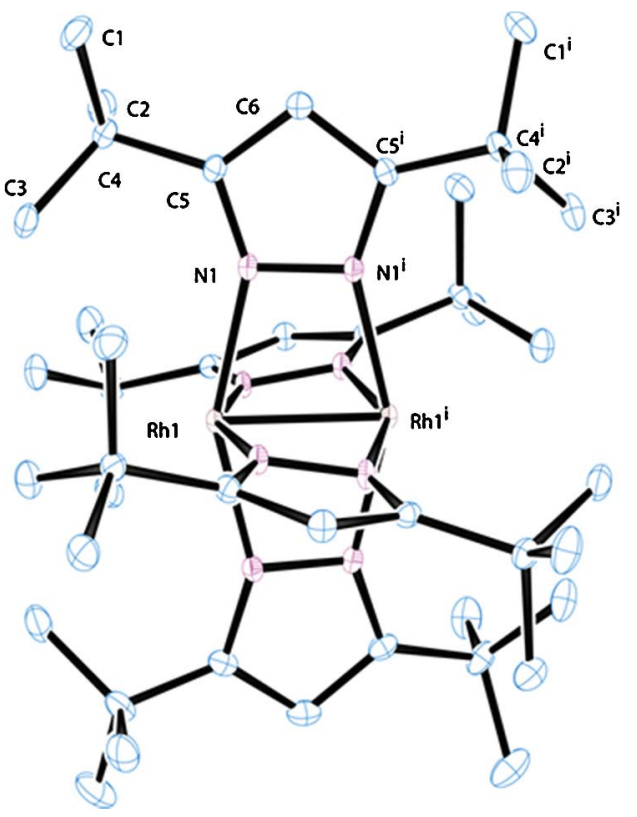

Fig. 3 ORTEP representation of $\mathrm{Rh}_{2}\left(\mu-3,5-\left({ }^{t} \mathrm{Bu}\right)_{2} \mathrm{Pz}\right)_{4}(3)$ with thermal ellipsoids at the $30 \%$ probability level. Hydrogen atoms have been omitted for clarity.

To the best of our knowledge, the $\mathrm{Rh}-\mathrm{Rh}$ bond distance of 2.305 $\AA$ observed in complex $\mathbf{3}$ is the shortest reported for a quadruplybridged dinuclear Rh(II)-Rh(II) complex. In fact, all four complexes exhibit shorter $\mathrm{Rh}-\mathrm{Rh}$ bond lengths compared to other quadruply bridged $\mathrm{Rh}$ (II) compounds which have carboxylato or hydroxypyridine ligands where the $\mathrm{Rh}-\mathrm{Rh}$ bond length ranges from 2.350-2.550 $\AA .{ }^{12}$ The shorter $\mathrm{Rh}-\mathrm{Rh}$ interaction in 3 may be a result of several factors. The common $\mu$-exobidentate coordination mode of the pyrazolate ligand is capable of supporting a wide range of $\mathrm{M}-\mathrm{M}$ separations, depending on the metal. Additionally, the bulky ${ }^{t} \mathrm{Bu}$ groups of complex $\mathbf{3}$ sterically hinder coordination of small $\sigma$ donor molecules at the open axial sites of each $\mathrm{Rh}$ atom, preventing donation of electron density into the $\sigma^{*}{ }_{\mathrm{Rh}-\mathrm{Rh}}$ LUMO of the molecule. Complex 3 did not form adducts which could 
be isolated when dissolved in a variety of donor solvents such as THF, acetonitrile, and acetone.

In order to probe the steric and electronic effects of the pyrazolate ligand on $\mathrm{Rh}_{2}(\mathrm{Pz})_{4}$ species, the asymmetrically substituted pyrazole $\left(3-\left(\mathrm{CF}_{3}\right), 5-\left({ }^{t} \mathrm{Bu}\right)\right) \mathrm{PzH}$, was used for the synthesis of complex 4. Prepared similarly to complexes 1-3, the solid state structure of $\mathbf{4}$ is shown in Fig. 4. The pyrazolate ligands adopt an alternating configuration so that $\mathrm{CF}_{3}$ and ${ }^{t} \mathrm{Bu}$ groups are adjacent to each other and this presumably minimizes steric interactions. Of related interest are the examples of $\mathrm{Rh}_{2}(\mathrm{mhp})_{4}$ complexes (mhp $=$ anion of 2-hydroxy-6-methyl-pyridine) in which three of the ligands are oriented in the same direction. ${ }^{13}$ The observed 3:1 ligand arrangement of these complexes is a result of steric constraints imposed by the coordination of either ligand or solvent at only one of the axial sites.

The $\mathrm{Rh}$ atoms of complex 4 reside on a twofold rotation axis, and are bisected by an inversion center, giving the molecule $S_{4}$

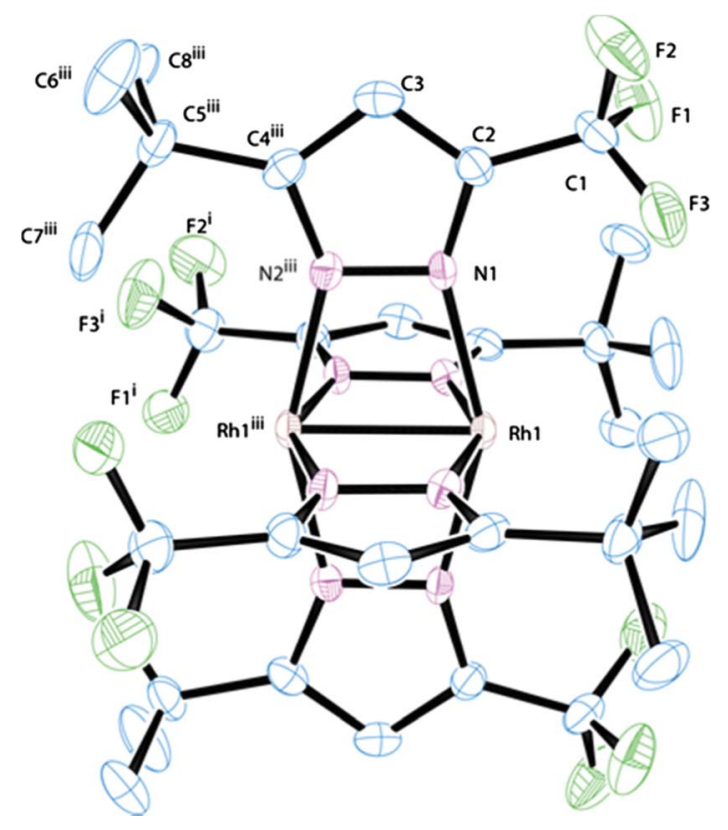

Fig. 4 ORTEP representation of $\mathrm{Rh}_{2}\left(\mu-3-\left(\mathrm{CF}_{3}\right), 5-\left({ }^{t} \mathrm{Bu}\right) \mathrm{Pz}\right)_{4}$ (4) with thermal ellipsoids at the $30 \%$ probability level. Hydrogen atoms have been omitted for clarity. symmetry. The $\mathrm{Rh}-\mathrm{N}$ distances for the nitrogen atoms closest to the $\mathrm{CF}_{3}$ substituent on each ligand are longer than at the opposite nitrogen $(\mathrm{Rh}(1)-\mathrm{N}(1)=2.069 \AA, \mathrm{Rh}(1)-\mathrm{N}(2)=2.033 \AA)$. The significant contraction of only one $\mathrm{Rh}-\mathrm{N}$ bond is explained by electronic effects of the substituents on the pyrazole ring. The strongly electron withdrawing $\mathrm{CF}_{3}$ group at the 3-position of the ring enhances the basicity of the distal nitrogen, causing a stronger $\mathrm{Rh}-\mathrm{N}$ interaction. ${ }^{14}$ The unequal $\mathrm{Rh}-\mathrm{N}$ bond lengths causes a slight tilting of each ligand with respect to the $\mathrm{Rh}-\mathrm{Rh}$ bonding axis $\left(\mathrm{Rh}(1)-\mathrm{N}(1)-\mathrm{C}(2)=150.39^{\circ}\right.$ is slightly more obtuse than $\left.\mathrm{Rh}(1)^{\mathrm{i}}-\mathrm{N}(2)^{\mathrm{i}}-\mathrm{C}(4)^{\mathrm{i}}=146.08^{\circ}\right)$. This tilting is also favored on steric grounds, as the alternating orientation of the pyrazolate ligands allows for relief of steric strain imposed by the bulky substituents. As in complex 3, the lack of coordinated donor ligands in the axial positions of $\mathbf{4}$ leads to a relatively short $\mathrm{Rh}-\mathrm{Rh}$ interaction $(2.308 \AA)$. Other key bond lengths and angles are listed in Table 4.

The ${ }^{1} \mathrm{H}$ NMR spectrum of $\mathbf{4}$ in $\mathrm{CDCl}_{3}$ shows the expected 9:1 ratio of ${ }^{t} \mathrm{Bu}$ : aromatic $\mathrm{Pz}$ proton resonances, while the ${ }^{19} \mathrm{~F}$ NMR spectrum reveals a singlet at $-58.8 \mathrm{ppm}$, indicative of one coordination environment for the fluorine atoms of the $\mathrm{CF}_{3}$ groups. Chemical ionization mass spectral analysis of the complex shows $m / e=970\left(\mathbf{M}^{+}\right)$as the highest peak, with a smaller peak at $m / e=951$ indicating loss of one fluorine atom.

\section{Thin film growth and characterization}

Complexes 1-4 are sufficiently volatile for CVD growth at $10^{-3}$ Torr, and the results of our preliminary thin film growth studies with 1, 3 and 4 are reported here. Complex $\mathbf{2}$ appears to lose $\mathrm{MeCN}$ and decomposes when heated under a dynamic vacuum and so we chose not to study it for use as a CVD precursor. Typical CVD experimental conditions and compositions of $\mathrm{Rh}$ thin films are shown in Table 5 which also contains data on films grown from other precursors in previous studies. All deposition experiments were performed in a horizontal hot-wall CVD reactor with ultra-high purity hydrogen as the carrier gas. In a typical deposition, a saturator tube was charged with approximately 10 $20 \mathrm{mg}$ of sample and the gas flow rate was varied to allow for optimal film growth. Each precursor was heated to a temperature deemed adequate to sufficiently volatilize the complex, while the

Table 5 Summary of deposition conditions and film composition for Rh films deposited in this work as well as from other precursors suitable for CVD of Rh thin films

\begin{tabular}{|c|c|c|c|c|c|c|c|}
\hline \multirow[b]{2}{*}{ Precursor $^{a}$} & \multirow[b]{2}{*}{ Carrier gas } & \multirow[b]{2}{*}{ Precursor temperature $\left({ }^{\circ} \mathrm{C}\right)$} & \multirow[b]{2}{*}{ Deposition temperature $\left({ }^{\circ} \mathrm{C}\right)$} & \multicolumn{3}{|c|}{ Film composition (at. $\%)^{b}$} & \multirow[b]{2}{*}{ Reference } \\
\hline & & & & $\mathrm{Rh}$ & $\mathrm{C}$ & $\mathrm{O}$ & \\
\hline 1 & $\mathrm{H}_{2}$ & 140 & 400 & 91 & 5 & 4 & This work \\
\hline 3 & $\mathrm{H}_{2}$ & 180 & 400 & 82 & 15 & 3 & This work \\
\hline 4 & $\mathrm{H}_{2}$ & 210 & 550 & 72 & 24 & 4 & This work \\
\hline $\mathrm{Rh}_{2}(\mu-\mathrm{Cl})_{2}(\mathrm{CO})_{4}$ & $\mathrm{H}_{2}$ & & 180 & 91 & 7 & 2 & $6 a$ \\
\hline $\mathrm{RhCp}(\mathrm{CO})_{2}$ & $\mathrm{H}_{2}$ & & 180 & 89 & 7 & 4 & $6 a$ \\
\hline $\mathrm{RhCp}(\mathrm{COD})$ & $\mathrm{H}_{2}$ & & 230 & 97 & 3 & 0 & $6 a$ \\
\hline $\mathrm{Rh}($ allyl $)(\mathrm{CO})_{2}$ & $\mathrm{H}_{2}$ & & 180 & 94 & 6 & 0 & $6 a$ \\
\hline $\mathrm{Rh}(\text { allyl })_{3}$ & $\mathrm{H}_{2}$ & & 130 & 96 & 4 & 0 & $6 a$ \\
\hline $\mathrm{Rh}(\mathrm{acac})_{3}$ & $\mathrm{O}_{2}$ & & 250 & 96 & 2 & 2 & 18 \\
\hline
\end{tabular}

${ }^{a} \mathrm{Cp}=$ cyclopentadienyl, $\mathrm{COD}=1,5$-cyclooctadiene, acac $=$ acetyl acetonate. ${ }^{b}$ via XPS after $30 \mathrm{~s}$ sputter with $\mathrm{Ar}^{+}$or by TOF-ERDA (for film from $\left.\operatorname{Rh}(\operatorname{acac})_{3}\right)$. 
deposition chamber was maintained at the lowest temperature in which deposition occurred.

Complex 4 showed a significantly higher sublimation temperature than $\mathbf{1}$ and $\mathbf{3}$, and required a higher temperature to affect deposition. All three precursors produced lustrous films that adhered well to the substrate. Typical X-ray diffraction patterns of films deposited under $\mathrm{H}_{2}$ are shown in Fig. 5. Broad peaks observed at $2 \Theta=41^{\circ}$ and $47^{\circ}$ correspond to the (111) and (200) planes of ccp $\mathrm{Rh}$, respectively. Crystallite size was estimated for each film from the Scherrer equation using the two most intense reflections, and was found to be between 8 and $12 \mathrm{~nm}$. The film deposited from complex $\mathbf{4}$ shows a slight increase in grain size due to the higher deposition temperature of $550^{\circ} \mathrm{C}$. Film thicknesses and morphology were investigated by cross-sectional SEM. Fig. 6 shows the surface morphology of a typical film deposited from complex 4. Average grain size for all films is estimated to be $30-50$ $\mathrm{nm}$ from HR-SEM images.

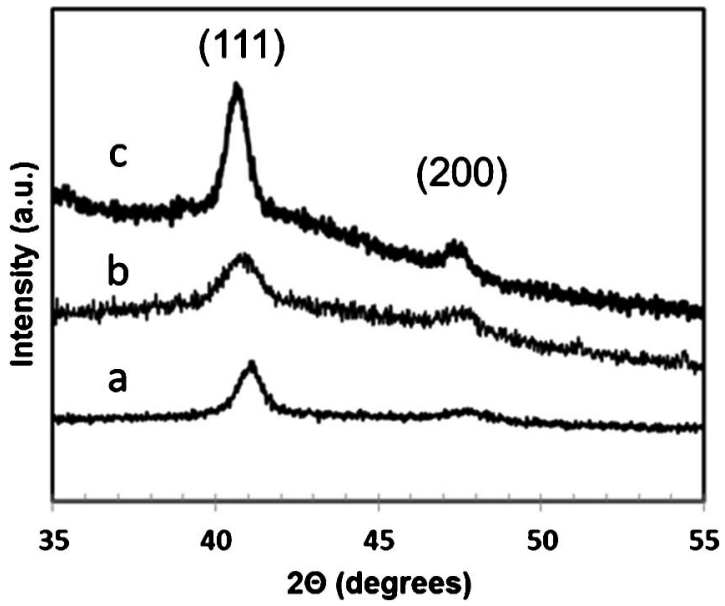

Fig. 5 XRD patterns of rhodium films grown from complex 1 (a), complex 3 (b), and complex 4 (c).

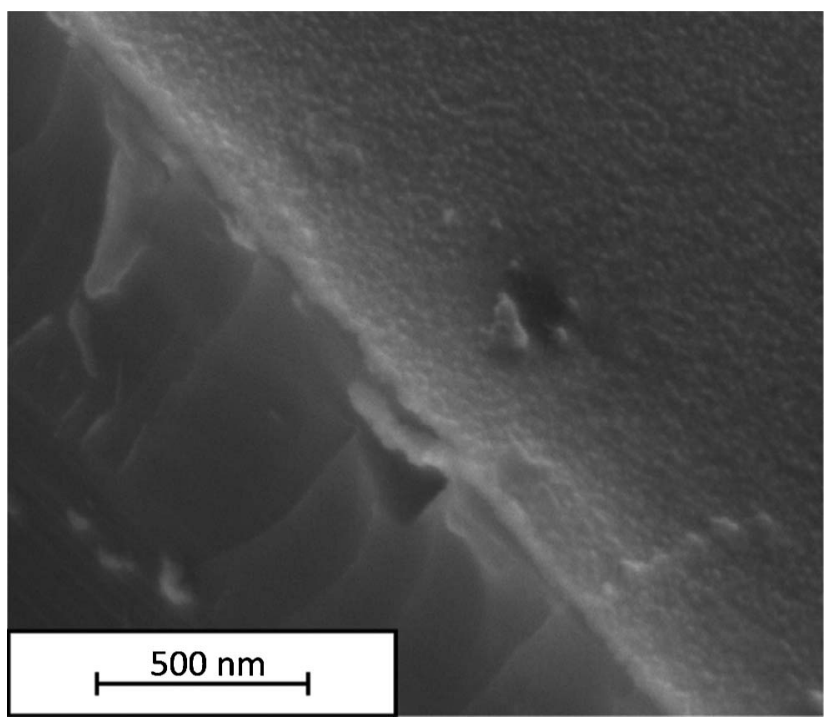

Fig. 6 SEM micrograph of a typical film grown from complex 4.

XPS measurements of the films determined the location of the $\mathrm{Rh} 3 \mathrm{~d}_{3 / 2}$ and $3 \mathrm{~d}_{5 / 2}$ peaks at $311.9 \mathrm{eV}$ and $307.2 \mathrm{eV}$, respectively, which are in good agreement with the binding energy for elemental $\mathrm{Rh}$. The peaks show very little asymmetry, indicative of a single electronic environment for the metal. Carbon and oxygen impurities of each film were quantified after gentle $\mathrm{Ar}^{+}$sputtering of the surface for $60 \mathrm{~s}$, and were found to be 5-24 at.\% for carbon and 3-4 at.\% for oxygen. Nitrogen and fluorine 1 s peaks were not apparent, indicating that $\mathrm{N}$ and $\mathrm{F}$ content is below the detection limit for all films. Though oxygen contamination remained approximately constant for each film, the carbon content of the film grown from complex 1 (5 at.\%) was noticeably lower compared to the films grown from 3 and 4 (15 and 24 at.\%, respectively). It seems likely that the increased mol.\% carbon in films grown from $\mathbf{3}$ and $\mathbf{4}$ is due to the presence of the ${ }^{t} \mathrm{Bu}$ groups in their Pz ligands. However, despite not having the highest $\mathrm{mol} \%$ carbon in the precursor, the film from complex $\mathbf{4}$ showed the highest levels of carbon. This could be due to the higher deposition temperature required to afford film growth for 4 . At the higher temperature an increased level of ligand decomposition might be expected. In general, it appears that the CVD precursors described in this work give $\mathrm{Rh}$ thin films of comparable purity to those previously described in the literature. ${ }^{19}$ It should also be noted that our studies represent preliminary results and the conditions for film formation have not been optimized. Direct comparisons with other studies are also difficult due to the use of different reactor conditions.

\section{Conclusions}

In conclusion, several new dinuclear rhodium pyrazolate complexes have been synthesized, structurally characterized, and shown to be viable precursors for deposition of high purity $\mathrm{Rh}$ thin films. The simple synthetic procedure, high volatility, and low toxicity of the precursors make these attractive alternatives to other volatile $\mathrm{Rh}$ complexes for CVD applications. It has also been demonstrated that the thermal properties of the precursors may be varied by modification of the substituents in the 3 and 5 positions of the pyrazolate ligands.

\section{Experimental}

\section{General procedures}

Unless otherwise noted, all reactions were performed under a dry, oxygen-free nitrogen atmosphere or under vacuum using standard Schlenk line and dry box techniques. All solvents were dried prior to use by distillation from molten sodium or sodium benzophenone ketyl under nitrogen. 3,5bis(trifluoromethyl) pyrazole, ${ }^{15} 3,5$-di-tert-butylpyrazole, ${ }^{16}$ and 3trifluoromethyl-5-tert-butyl pyrazole ${ }^{17}$ were prepared according to literature procedures. Melting points were determined in sealed capillaries under $\mathrm{N}_{2}(1 \mathrm{~atm})$ on an Electrothermal Melting Point apparatus and are uncorrected. ESI mass spectra were collected on a Finnigan MAT TSQ 700 mass spectrometer. NMR spectra were recorded on a Varian 300 Unity Plus spectrometer (300 $\mathrm{MHz}$ at $298 \mathrm{~K}$ ). Chemical shifts are referenced to the deuterated solvent. Infrared spectra were taken on a Nicolet IR 200 FTIR spectrometer between $\mathrm{KBr}$ plates. 


\section{Synthesis of $\mathrm{Rh}_{2}\left(\mu-3,5-\left(\mathrm{CF}_{3}\right)_{2} \mathrm{Pz}\right)_{4} \cdot 2 \mathrm{H}_{2} \mathrm{O}$ (1)}

A solution of $n$-butyllithium $(0.8 \mathrm{~mL}, 1.6 \mathrm{M})$ in hexane was added dropwise to a solution of 3,5-bis(trifluoromethyl)pyrazole $(0.24 \mathrm{~g}$, $1.17 \mathrm{mmol})$ in diethyl ether $(25 \mathrm{~mL})$ at $-78^{\circ} \mathrm{C}$. This was allowed to warm to room temperature, and was stirred for $3 \mathrm{~h}$. This solution was then added dropwise to a heterogeneous solution of anhydrous rhodium acetate $(0.13 \mathrm{~g}, 0.29 \mathrm{mmol})$ in $10 \mathrm{~mL}$ diethyl ether. The resulting reaction mixture was stirred for $12 \mathrm{~h}$ at room temperature, and was then filtered. The filtrate was evaporated to dryness under vacuum and the yellow brown residue was extracted with hexane $(3 \times 10 \mathrm{~mL})$ and then filtered through a $2 \mathrm{~cm}$ bed of Celite. Orange $\mathrm{X}$-ray quality crystals were grown from this solution at $-30{ }^{\circ} \mathrm{C}$. Suitable crystals may also be grown by sublimation under vacuum at $140{ }^{\circ} \mathrm{C}$ in a sealed glass tube. Isolated: $0.19 \mathrm{~g}, 64 \%$; mp 139$141{ }^{\circ} \mathrm{C}$. (subl.); ${ }^{1} \mathrm{H}-\mathrm{NMR}\left(300 \mathrm{MHz}, \delta, \mathrm{CDCl}_{3}\right.$ ): 6.37 (s), 1.58 (s, br); ${ }^{19} \mathrm{~F}-\mathrm{NMR}\left(\mathrm{CDCl}_{3}\right): \delta-61.80(\mathrm{~s})$; FT-IR $\left(\mathrm{KBr}, \mathrm{cm}^{-1}\right): 3601(\mathrm{w})$, 3159 (w), 2920 (m, br), 2851 (m), 2117 (s), 1260 (m), 1138 (m), $1021(\mathrm{~m})$. HRMS (chemical ionization) $\mathrm{m} / \mathrm{e}$ : $1017.8278\left[\mathrm{M}^{+}-\right.$ $\left.2 \mathrm{H}_{2} \mathrm{O}\right], 998.8300\left[\mathrm{M}^{+}-\mathrm{F}-2 \mathrm{H}_{2} \mathrm{O}\right]$. Calcd. for $\mathrm{C}_{20} \mathrm{H}_{8} \mathrm{~F}_{24} \mathrm{~N}_{8} \mathrm{O}_{2} \mathrm{Rh}_{2}$ : C, 23.59; H, 0.40; N, 11.01. Found: C, 22.56; H, 0.42; N, 11.36 .

\section{Synthesis of $\mathrm{Rh}_{2}\left(\mu-3,5-\left(\mathrm{CF}_{3}\right)_{2} \mathrm{Pz}\right)_{4} \cdot 2 \mathrm{CH}_{3} \mathrm{CN}$ (2)}

To a solution of $0.050 \mathrm{~g}$ of $\mathbf{2}$ in $10 \mathrm{~mL}$ hexane was added $1 \mathrm{~mL}$ acetonitrile. The orange solution immediately turned yellow. Yellow crystals developed after slow evaporation of this solution. Isolated: $0.48 \mathrm{~g}, 90 \%$; mp 219-220 ${ }^{\circ} \mathrm{C}$. (dec.); ${ }^{1} \mathrm{H}-\mathrm{NMR}(300 \mathrm{MHz}$, $\left.\delta, \mathrm{CDCl}_{3}\right): 6.30(\mathrm{~s}, 4 \mathrm{H}), 2.68(\mathrm{~s}, 6 \mathrm{H}) ;{ }^{19} \mathrm{~F}-\mathrm{NMR}\left(\mathrm{CDCl}_{3}\right): \delta-61.62$ (s); FT-IR (KBr, cm $\left.{ }^{-1}\right): 2917(\mathrm{w}), 1538(\mathrm{~m}), 1493(\mathrm{~m}), 1272$ (s), $1222(\mathrm{~s}), 1132(\mathrm{~s}), 1021(\mathrm{~s}), 811(\mathrm{~m})$. HRMS (chemical ionization) $m / e$ : $1058.8578\left[\mathrm{M}^{+}-\mathrm{H}_{3} \mathrm{CCN}\right], 1039.8574\left[\mathrm{M}^{+}-\mathrm{H}_{3} \mathrm{CCN}-\right.$ $\mathrm{F}], 1017.8280\left[\mathrm{M}^{+}-2 \mathrm{H}_{3} \mathrm{CCN}\right]$. Calcd. for $\mathrm{C}_{24} \mathrm{H}_{10} \mathrm{~F}_{24} \mathrm{~N}_{10} \mathrm{Rh}_{2}$ : C, 26.20; H, 0.92; N, 12.73. Found: C, 26.17; H, 0.67; N, 12.83 .

\section{Synthesis of $\mathrm{Rh}_{2}\left(\mu-3,5-\left({ }^{t} \mathrm{Bu}\right)_{2} \mathrm{Pz}\right)_{4}(3)$}

A solution of $n$-butyllithium $(1.5 \mathrm{~mL}, 1.6 \mathrm{M})$ in hexane was added dropwise to a solution of 3,5-di-tertbutylpyrazole $(0.424 \mathrm{~g}$, $2.35 \mathrm{mmol})$ in diethyl ether $(25 \mathrm{~mL})$ at $-78^{\circ} \mathrm{C}$. This was allowed to warm to room temperature, and was further stirred for 3 h. This solution was then added dropwise to a heterogeneous suspension of anhydrous rhodium acetate $(0.254 \mathrm{~g}, 0.57 \mathrm{mmol})$ in $10 \mathrm{~mL}$ diethyl ether. After several minutes of stirring, the color of the mixture became forest green and more homogeneous. The resulting reaction mixture was stirred for $12 \mathrm{~h}$ at room temperature and was then filtered. The filtrate was evaporated to dryness under vacuum and the residue was extracted with hexane $(3 \times 10 \mathrm{~mL})$ and then filtered through a $2 \mathrm{~cm}$ bed of Celite. Green X-ray quality crystals were grown from this solution at $-30{ }^{\circ} \mathrm{C}$. Suitable crystals may also be grown by sublimation under vacuum at $180{ }^{\circ} \mathrm{C}$ in a sealed glass tube. Isolated: $0.40 \mathrm{~g}, 75 \%$; mp $235-237{ }^{\circ} \mathrm{C}$.; ${ }^{1} \mathrm{H}-\mathrm{NMR}$ (300 MHz, $\delta, \mathrm{CD}_{2} \mathrm{Cl}_{2}$ ): 5.92 (s, $4 \mathrm{H}$ ), 1.29 (s, $72 \mathrm{H}$ ); FT-IR (KBr, $\mathrm{cm}^{-1}$ ): 2943 (m, br), 1412 (m), 1352 (m), 1217 (w). HRMS (chemical ionization) $m / e$ : $922.4295\left[\mathrm{M}^{+}\right]$. Calcd. for $\mathrm{C}_{44} \mathrm{H}_{76} \mathrm{~N}_{8} \mathrm{Rh}_{2}$ : C, 57.26; H, 8.30; N, 12.14. Found: C, 57.18; H, 8.96; N, 12.50 .

\section{Synthesis of $\mathrm{Rh}_{2}\left(\mu-3-\left(\mathrm{CF}_{3}\right), 5-\left({ }^{t} \mathrm{Bu}\right) \mathrm{Pz}\right)_{4}(4)$}

A solution of $n$-butyllithium $(1.2 \mathrm{~mL}, 1.6 \mathrm{M})$ in hexane was added dropwise to a solution of 3-trifluoromethyl, 5-tertbutylpyrazole $(0.34 \mathrm{~g}, 1.89 \mathrm{mmol})$ in diethyl ether $(25 \mathrm{ml})$ at $-78^{\circ} \mathrm{C}$. This was allowed to warm to room temperature and was further stirred for $3 \mathrm{~h}$. This solution was then added dropwise to a heterogeneous solution of anhydrous rhodium acetate $(0.19 \mathrm{~g}, 0.43 \mathrm{mmol})$ in $10 \mathrm{~mL}$ diethyl ether. The resulting reaction mixture was stirred for $12 \mathrm{~h}$ at room temperature, and was then filtered. The filtrate was evaporated to dryness under vacuum and the brown residue was extracted with hexane $(3 \times 10 \mathrm{~mL})$ and filtered through a $2 \mathrm{~cm}$ bed of Celite. Green X-ray quality crystals were grown from this solution after one week at $-30{ }^{\circ} \mathrm{C}$. Isolated: $0.31 \mathrm{~g}, 72 \%$; mp $235-$ $237{ }^{\circ} \mathrm{C}$; ${ }^{1} \mathrm{H}-\mathrm{NMR}\left(300 \mathrm{MHz}, \delta, \mathrm{CDCl}_{3}\right.$ ): 5.85 (s, $\left.4 \mathrm{H}\right), 1.34$ (s, 36 $\mathrm{H}) ;{ }^{19} \mathrm{~F}-\mathrm{NMR}\left(\mathrm{CDCl}_{3}\right): \delta-58.71(\mathrm{~s}) ; \mathrm{FT}-\mathrm{IR}\left(\mathrm{KBr}, \mathrm{cm}^{-1}\right): 2920(\mathrm{w})$, $1701(\mathrm{~m}), 1256$ (s), 1121 (s). HRMS (chemical ionization) $\mathrm{m} / \mathrm{e}$ : $970.1292\left[\mathrm{M}^{+}\right], 955.1057\left[\mathrm{M}^{+}-\mathrm{CH}_{3}\right], 951.1306\left[\mathrm{M}^{+}-\mathrm{F}\right]$. Calcd. for $\mathrm{C}_{32} \mathrm{H}_{40} \mathrm{~F}_{12} \mathrm{~N}_{8} \mathrm{Rh}_{2}$ : C, 39.60; H, 4.15; N, 11.55. Found: C, 40.08; $\mathrm{H}, 4.21 ; \mathrm{N}, 11.50$.

\section{Thin film deposition studies}

Films were grown in a horizontal, hot-wall CVD reactor consisting of an approximately $2^{\prime \prime}$ diameter Pyrex tube heated by a tube furnace. The precursor was heated in a saturator tube connected to the deposition assembly by VCR and Swagelok type connections. Ultra high purity hydrogen $(99.999 \%)$ was used as the carrier gas at flow rates of 5-50 sccm controlled by a Fathom Technologies mass flow controller, with the overall pressure of the system maintained between 0.5 and 2 Torr. The temperature of the precursor was controlled by an oil bath, while the lines were heated separately with insulated heating tape. Films were grown on $\mathrm{Si}(100)$ wafers with native oxide cut into approximately $1 \mathrm{~cm} \times 1 \mathrm{~cm}$ squares. The wafers were prepared by sequentially sonicating in hexane, isopropanol, and DI water, and then drying at $120^{\circ}$ for $1 \mathrm{~h}$. XPS measurements were carried out on a Kratos AXIS Ultra DLD (monochromatic $\mathrm{Al} \mathrm{K} \alpha$ ), and depth profiling was achieved by sputtering the film with $4 \mathrm{kV} \mathrm{Ar}{ }^{+}$. X-Ray diffraction patterns were collected on a Bruker - Nonius D8 ADVANCE diffractometer. Film thicknesses were determined using cross-sectional SEM (Hitachi S-5500 and FEI Quanta 650).

\section{Single crystal X-ray crystallography}

Data were collected with graphite monochromated Mo $\mathrm{K} \alpha$ radiation $(\lambda=0.71073 \AA$ ) on a Nonius Kappa CCD diffractometer at $153 \mathrm{~K}$ (complexes 3 and 4) and a Rigaku AFC-12 with Saturn 724+ CCD at $100 \mathrm{~K}$ (complexes 1 and 2). All structures were solved by direct methods and were refined anisotropically using full-matrix least-squares methods with the SHELX 97 program package. The coordinates of the non-hydrogen atoms were refined anisotropically, while hydrogen atoms were included in the calculation isotropically but not refined. See ESI $\uparrow$ for crystallographic data in CIF format. Details of crystallographic parameters, data collection, and refinements are listed in Table 1 . 


\section{Acknowledgements}

The authors would like to thank the Welch Foundation (Grant F-816) and the Petroleum Research Fund, administered by the American Chemical Society (47014-ACS) for financial support. X-Ray data were collected on instrumentation purchased with funds from NSF grant \#0741973.

\section{References}

1 (a) G. Hass, J. Opt. Soc. Am., 1982, 72, 27; (b) L. Marot, G. De Temmerman, V. Thommen, D. Mathys and P. Oelhafen, Surf. Coat. Technol., 2008, 202, 2837.

2 (a) V. Dal Santo, C. Mondelli, V. De Grandi, A. Gallo, S. Recchia, L. Sordelli and R. Psaro, Appl. Catal., A, 2008, 346, 126; (b) F. J. Williams, M. S. Tikhov, A. Palermo, N. Macleod and R. M. Lambert, J. Phys. Chem. B, 2001, 105, 2800.

3 (a) M. W. Lane, C. E. Murray, F. R. McFeely, P. M. Vereecken and R. Rosenberg, Appl. Phys. Lett., 2003, 83, 2330; (b) I. Goswami and R. Laxman, Semicond. Int., 2004, 27, 49.

4 J. R. Renzas and G. A. Somorjai, J. Phys. Chem. C, 2010, 114, 17660.

5 (a) J.-P. Lu, P. W. Chu, R. Raj and H. Gysling, Thin Solid Films, 1992 208, 172; (b) E. B. Flint, J. Messelhaeuser and H. Suhr, Appl. Surf. Sci., 1992, 54, 56; (c) E. L. Crane, Y. You, R. G. Nuzzo and G. S. Girolami, J. Am. Chem. Soc., 2000, 122, 3422.

6 (a) R. Kumar and R. J. Puddephatt, Can. J. Chem., 1991, 69, 108; (b) J. S. Cohan, H. Yuan, R. S. Williams and J. I. Zink, Appl. Phys. Lett., 1992, 60, 1402.
7 (a) A. Waheed, R. A. Jones, K. Agapiou, X. Yang, J. A. Moore and J. G. Ekerdt, Organometallics, 2007, 26, 6778; (b) Z. Wang, C. D. Abernethy, A. H. Cowley, J. N. Jones, R. A. Jones, C. L. B. Macdonald and L. Zhang, J. Organomet. Chem., 2003, 666, 35.

8 (a) Y.-H. Song, Y.-L. Chen, Y. Chi, C.-S. Liu, W.-L. Ching, J.-J. Kai, R.-S. Chen, Y.-S. Huang and A. J. Carty, Chem. Vap. Deposition, 2003, 9, 162; (b) Y. Chi, H.-L. Yu, W.-L. Ching, C.-S. Liu, Y.-L. Chen, T.-Y. Chou, S.-M. Peng and G.-H. Lee, J. Mater. Chem., 2002, 12, 1363; (c) O. E. El-Kadri, M. J. Heeg and C. H. Winter, Dalton Trans., 2006, 16, 1943.

9 A. R. Barron, G. Wilkinson, M. Motevalli and M. B. Hursthouse, Polyhedron, 1985, 4, 1131.

10 F. Breher and H. Rueegger, Angew. Chem., Int. Ed., 2005, 44, 473.

11 R. Garcia, H. Adams and N. J. Patmore, Dalton Trans., 2009, 2, 259.

12 F. A. Cotton and R. A. Walton, Multiple Bonds Between Metal Atoms, John Wiley and Sons, 1982, pp. 311-323.

13 F. A. Cotton and T. R. Felthouse, Inorg. Chem., 1981, 20, 584.

14 Z. Hu, A. Loas and S. M. Gorun, Inorg. Chim. Acta, 2009, 362, 4639.

15 P. P. K. Claire, P. L. Coe, C. J. Jones and J. A. McCleverty, J. Fluorine Chem., 1991, 51, 283.

16 C. Fernandez-Castano, C. Foces-Foces, N. Jagerovic and J. Elguero, $J$. Mol. Struct., 1995, 355, 265.

17 K. N. Zelenin, A. R. Tugusheva, S. I. Yakimovich, V. V. Alekseev and E. V. Zerova, Chem. Heterocycl. Compd., 2002, 38, 668.

18 T. Aaltonen, M. Ritala and M. Leskelae, Electrochem. Solid-State Lett., 2005, 8, C99.

19 J.-C. Hierso, R. Feurer and P. Kalck, Coord. Chem. Rev., 1998, 178, 1811. 